\title{
Electrical impressions
}

\section{K. Tschechowitsch}

To cite this article: K. Tschechowitsch (1888) Electrical impressions, Philosophical Magazine Series 5, 25:152, 80-80, DOI: 10.1080/14786448808628155

To link to this article: http://dx.doi.org/10.1080/14786448808628155

曲 Published online: 29 Apr 2009.

13 Submit your article to this journal 준

Џll Article views: 2

Q View related articles $₫$ 
differences of potential. It was the same, whether the current went through the whole, or half the length of the tube. The constant $b$ was found by Prof. Quincke for ordinary German glass to be almost equal :

$$
\begin{aligned}
& \text { For water } \ldots \ldots \ldots \ldots \ldots .0 .000055 \text { to } 0.000067 \\
& \text { For ethylic alcohol ........ } 0.000034
\end{aligned}
$$

The resistance of the liquids altered considerably during the experiments. In the mean it was as follows:-

$$
\begin{aligned}
& \text { Resistance of the Specific resistance, } \\
& \text { entire column of liquid. } \quad \mathrm{Hg}=1 \text {. } \\
& \text { Water ............ } 319.10^{7} \text { ohms } \quad 4722.10^{6} \\
& \text { Metbyl alcohol ......... } 430.10^{7} \text { ohms } \quad 6365.10^{6} \\
& \text { Ethylic alcohol ......... 1570.10 } 10^{7} \text { ohms } 23350.10^{6}
\end{aligned}
$$

If greater forces were used, water showed a sudden change of resistance as soon as the electrical force $\mathrm{P} / a$ in the liquid exceeded a certain limiting value; the deflection of the galvanometer-needle exhibited a sudden fall of potential. This sudden fall is analogous to that whicb is observed in dielectric liquids, and is explained by the sudden occurrence of an electrolytic decomposition*. The limiting value of $\mathrm{P} / a$ for water is considerably less than for good insulating liquid dielectrics. As a rough approximation we may put for it the value 1.32 to 1.45 C.G.S. in the case of the whole length, and 1.61 to 1.98 C.G.S in the case of half the length.

I found no alteration with alcohol.

Observations on other dielectrics, as bisulphide of carbon, ether, oil of turpentine, and rape-oil, all showed a considerable transport in the direction of the positive current. I could not, however, obtain constant numbers.-Wiedemann's Annalen, No. 10, 1887.

\section{ELECTRICAL IMPRESSIONS. BY K. TSCHECHOWITSCH.}

If a glass plate is laid on tinfoil, and on the glass a coin, and if the two metals are connected with the two conductors of an electrical machine, then, as Karsten has shown, after a greater or less number of turns of the machine, the coin can be removed, and by breathing on the glass, an impression is produced of the coin which laid on the glass.

The author has observed that such impressions may be easily fixed on glass, if, instead of breathing on the glass, it be coated with a dilute solution of stearine, yellow oxide of mercury, oxide of zinc, or the like in benzol.

If the glass is covered with a thin layer of fat (vaseline is best) the coin leaves directly on the glass after electrification a perfectly distinct impression.

The figures differ with the kind of electricity with which the coin is charged.-Beiblätter der Physik, No. 10, 1887 (from the Journal of the Russian Physical and Chemical Society, 1887).

* Quincke, Wied. Ann. xxviii. p. 547 (1886). 